\title{
The Mini Incision Technique for Carpal Tunnel Decompression Using Nasal Instruments
}

\section{Karpal Tünel Dekompresyonunda Nazal Cerrahi Aletlerle Uygulanan Mini İnsizyon Tekniği}

\begin{abstract}
AIM: Mini incision techniques for carpal tunnel release have become increasingly popular for the treatment of carpal tunnel syndrome. The main advantages of mini incision techniques are shorter recovery and return-to-work time. However, the risk of neurovascular injury still remains worrisome. We present a novel method to release the carpal tunnel by using nasal instruments. This novel technique combines the advantages of endoscopic and open techniques while utilizing standard instruments. The advantages, disadvantages, and results of this technique are discussed.
\end{abstract}

MATERIAL and METHODS: Forty-five patients (15 male, 30 female, age 28-62; mean 48) with isolated carpal tunnel syndrome were enrolled to the study. A total of 55 wrists (bilateral in 7 cases, the right wrist in 41 and the left wrist in 14) underwent carpal tunnel decompression with a mini longitudinal incision technique. Grip strength - key pinch and sensorial evaluations were performed in all patients by one examiner using the Pressure-Specified Sensory Device.

RESULTS: Significant differences between the pre- and postoperative periods were observed in either grip strength or pinch strength $(p<0.05)$. No recurrence or injury to the neurovascular structures was noted in the follow-up period.

CONCLUSION: The technique is simple and effective, employs inexpensive instruments, and has a low complication rate.

KEYWORDS: Carpal tunnel syndrome, Limited incision technique, Mini incision technique, Nasal instruments, Pressure-specified sensory device (PSSD)

\section{Öz}

AMAÇ: Karpal tünelin cerrahi dekompresyonunda uygulanan mini insizyon teknikleri günümüzde sıkça tercih edilmeye başlanmıştır. Mini insizyon tekniklerinin avantajı iyileşme zamanının hızlı olması ve hastaların işe dönüş zamanının kısa olmasıdır. Bu çalışmada, karpal tünel dekompresyonunda nazal cerrahi aletlerin kullanıldığı yeni bir teknik tanımlanmıştır. Bu teknik hem endoskopik, hem de açık cerrahi tekniğinin avantajlarını sağlamaktadır. Bu tekniğin avantajları, dezavantajları ve cerrahi sonuçlar bu çalışmada tartışılmıştır.

YÖNTEM ve GEREÇ: Yaşları 28 ile 62 arasında arasında değişen 15 erkek ve 30 bayan olmak üzere toplam 45 hasta çalışmaya dahil edildi. 7 hastaya, bilateral karpal tünel dekompresyonu uyguland. Median sinirin duyusal değerlendirilmesi ve 'Grip' ile 'Pinch' kuvvetleri ‘Basınca Dayalı Duyu Cihazı' ile ölçüldü

BULGULAR: Preoperatif ve postoperatif periodlar arasında 'Grip' ile 'Pinch' kuvvetleri açısından önemli bir fark olduğu görüldü. Takip periyodu boyunca, nörovasküler yapılarda bir hasara ve rekürrense saptanmadı

SONUÇ: Tanımlanan mini insizyon tekniği basit ve etkili bir yöntem olup düşük komplikasyon oranına sahiptir.

ANAHTAR SÖZCÜKLER: Karpal tünel sendromu, Sınırlı insizyon tekniği, Mini insizyon tekniği, Nazal enstrümanlar, Basınca duyarlı duyu cihazı

\section{Celalettin SEVER \\ Yalcin KULAHCI \\ Sinan OKSUZ \\ Cihan SAHIN}

Gulhane Military Medical Academy and Medical Faculty, Haydarpaşa Training Hospital, Department of Plastic and Reconstructive Surgery and Burn Unit, Istanbul, Turkey

Received : 28.08.2009

Accepted : 12.05 .2010

Correspondence address: Celalettin SEVER

GATA Haydarpaşa Egitim Hastanesi, Plastik ve Rekonstruktif Cerrahi Servisi, Selimiye Mah. Tıbbiye Cad. 34668 Kadıköy, Istanbul, TURKEY Phone: +90 2165422656

E-mail: drcsever@hotmail.com 


\section{INTRODUCTION}

Carpal tunnel syndrome is the most frequent nerve compression disorder. It affects $1 \%$ and $5 \%$ of the general and working population using their hands and wrists in daily living (12). Surgical treatment is generally recommended in cases that fail to respond to conservative measures. A variety of surgical techniques have been described for the treatment of carpal tunnel syndrome. The first open carpal tunnel release was performed in 1924 by Mackinnon et al. in Mayo Clinic and popularized later by Phalen et al (1). Today, open carpal tunnel release through an interthenar incision is the standard procedure of choice for many surgeons.

The open incision technique has some disadvantages related to the procedure including an unsightly and tender scar, pillar pain, a long healing period and flexor tendon bowstringing (2-4). Recent studies aim to decrease these complications by mini open incisions and endoscopic release techniques. Although endoscopic release seems to avoid complications related to the incision, it is not a complication-free technique and laceration of the superficial palmar arc, median nerve transection, injuries of digital nerves, vessels, flexor tendons and insufficient release of the carpal tunnel are documented. Thus, the purported advantages of endoscopic carpal tunnel release must be balanced against potential injury to adjacent neurovascular structures. In addition, the endoscopic technique has a long learning curve, and it is costly due to the special equipment needed for this procedure (5-7).

In this study, we performed a novel mini incision technique by using nasal instruments to prevent complications related to the classical open release and endoscopic release. We aim to demonstrate that this technique combines the respective advantages of traditional open and endoscopic carpal tunnel releases. The novel mini incision technique is simple and effective and employs inexpensive instruments.

\section{PATIENTS AND METHODS}

Forty-five patients (15 male, 30 female, age 28-62; mean 48) with isolated carpal tunnel syndrome were enrolled to the study. The final diagnosis was based on the history of hand dysesthesia, paraesthesia, numbness in the median nerve distribution, a positive Phalen's flexion test finding and/or a positive Tinel's sign. All patients also underwent nerve conduction tests and had positive electrodiagnostic study findings.

A total of 55 wrists (bilateral in 7 cases, the right wrist in 41 and the left wrist in 14) underwent carpal tunnel decompression with a mini longitudinal incision technique. The patients were followed-up for 6 to 20 months (mean; 11). The sensory, grip strength, and pinch strength were assessed in operated hands of all patients both before surgery and after the follow-up period. Grip strength - key pinch and sensorial evaluations were performed in all patients by one examiner using the PressureSpecified Sensory Device [(PSSD), Sensory Management Services, Baltimore, USA] (Figure 1). All patients were seated in a reclining chair and were asked to close their eyes so that they could not see the computer screen or the hand being tested. A button linked to the computer was placed in the hand opposite to the hand being tested, and subjects were instructed to press the button to indicate perception of the test stimulus. The recovery of grip and pinch strength percentages were expressed in mean \pm SD (standard deviation) and $p$ values $<0.05$ were accepted as statistically significant.

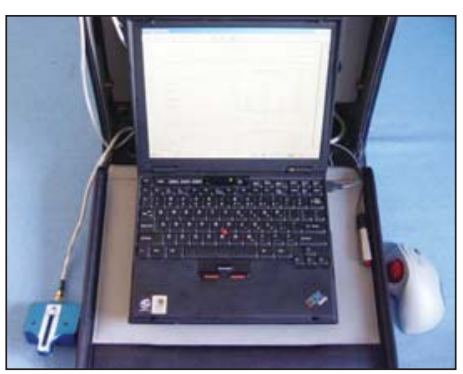

Figure 1: PressureSpecified Sensory Device.

\section{SURGICAL TECHNIQUE}

The mini incision technique was performed after local anesthesia with an upper- arm pneumatic tourniquet. The 1-cm first incision was marked in the palm, beginning at the intersection of Kaplan's cardinal line and a line drawn along the radial border of the third web. The $1.5 \mathrm{~cm}$ second skin incision was made on a line between palmaris longus and the flexor carpi ulnaris tendons. (Figure 2)

After the first skin incision, the subcutaneous tissue was incised with a no. 15 blade and two retractors were positioned to separate the edges of the incision. The palmar fascia was divided by blunt dissections. The distal edge of flexor retinaculum 
and median nerve was visualized. (Figure 3) After the second skin incision made at the wrist level, the proximal edge of the flexor retinaculum and median nerve was identified. (Figure 4)

A long nasal speculum (Figure 5) was then pushed proximally from the first incision to the second incision and introduced between the palmar fascia and the transverse carpal ligament. (Figure $6-$ Figure 7) A nasal septum knife (Ballenger) (Figure 8) was then gently pushed distally to divide the flexor retinaculum. (Figure 9) The flexor retinaculum between the blade and handle was completely incised under direct vision. (Figure 10)

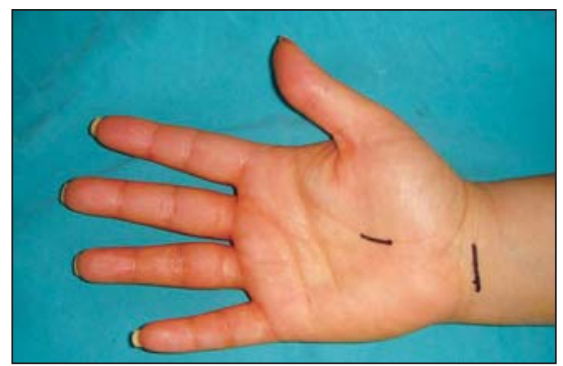

Figure 2: The skin incisions.

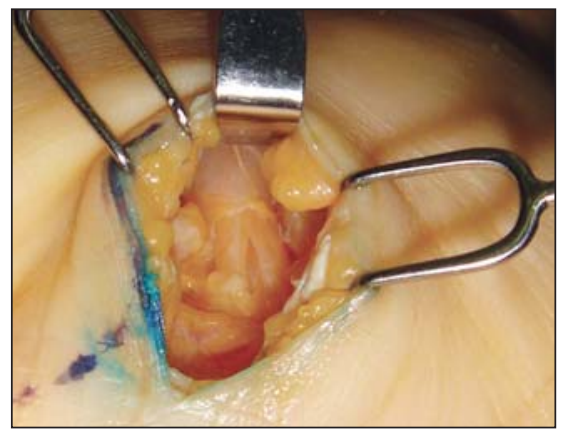

Figure 3: The distal edge of flexor retinaculum and median nerve.

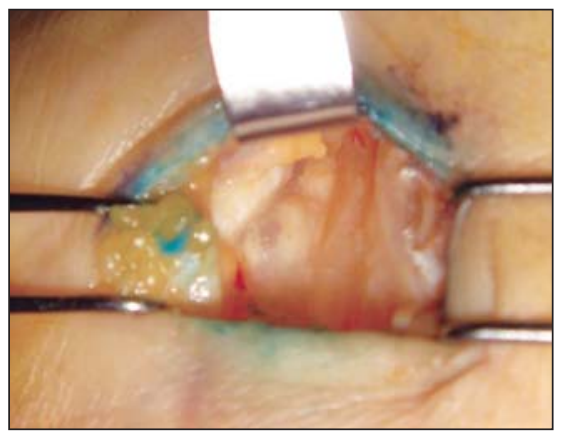

Figure 4: The proximal edge of the flexor retinaculum and median nerve.

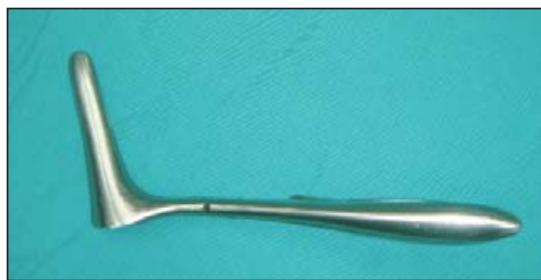

Figure 5: The Killian nasal speculum.
The incisions were closed with interrupted 4-0 nylon sutures and a pressure bandage was applied. The tourniquet was then released. No splint was used, and the patients were encouraged to move their hands and fingers in the immediate postoperative period. The original dressing was removed after 5 days, and the stitches were removed after 10 days.

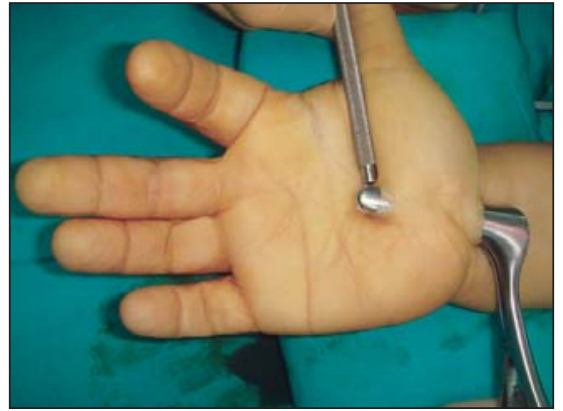

Figure 6: The nasal speculum between the palmar fascia and the transverse carpal ligament.

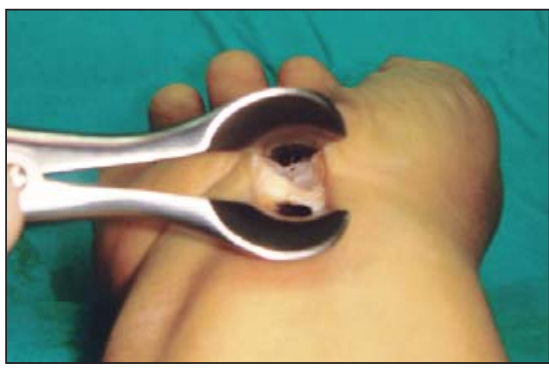

Figure 7: The flexor retinaculum ligament under direct visualization.

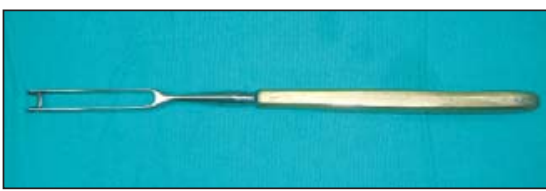

Figure 8: The nasal septum knife.

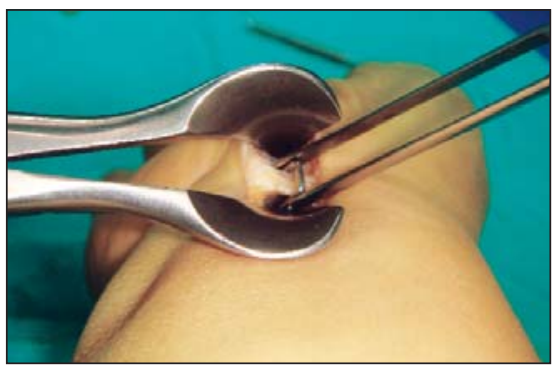

Figure 9: Release of the fexor retinaculum with using the nasal septum knife.

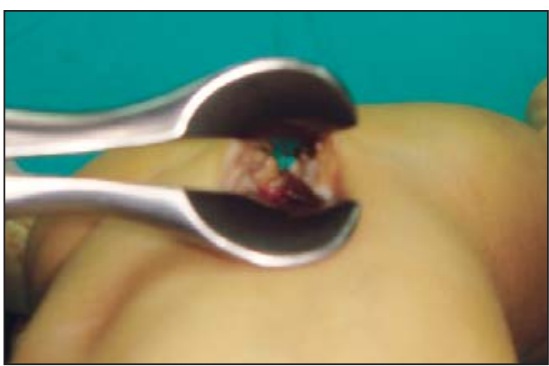

Figure 10: The completely divided fexor retinaculum. 


\section{RESULTS}

A total of 55 hands underwent carpal tunnel release in this study. Significant differences between the pre- and postoperative periods were observed in either grip strength or pinch strength $(\mathrm{p}<0.05)$. The preoperative and post-operative grip and pinch strength scores are shown in Table I. No recurrence or injury to the neurovascular structures was noted in the follow-up period.

\section{DISCUSSION}

Carpal tunnel syndrome is one of the most common compression neuropathies affecting peripheral nerves and is the commonest nerve entrapment syndrome in the upper limb. Carpal tunnel decompression surgery has evolved over the years to decrease the complications and side effects associated with the surgical procedures. Three different surgical techniques have been described in the literature -the classic or standard open approach, single or multiport endoscopic approach, and the limited incision approach (9). The standard open approach has been the optimal treatment procedure for surgical decompression of the median nerve, though it is still controversial. This technique has the advantage of direct visualization of the structures within the carpal tunnel but it may be associated with certain complications such as a painful scar with an incidence of $19 \%$ to $61 \%(8,10,11)$. Other complaints include superficial sensory nerve pain, neuromas, and "pillar" pain that may possibly result from small neuromas in the subcutaneous tissue. Pillar pain may decrease hand strength and delay the resumption of activities of daily living.

Although the endoscopic carpal tunnel release has been demonstrated to reduce recovery time, a previous study raised concerns about an increased rate of complications related to the incision. However, fewer complications such as persistent weakness and scar tenderness have now been demonstrated with the improvement in the endoscopic techniques $(9,12,13)$. The purported advantages of endoscopic carpal tunnel release must therefore be balanced against potential injury to adjacent neurovascular structures. In addition, the procedure lengthens operating time and the surgeon requires special training and equipment, requiring a hospital or a facility with endoscopic equipment (14).

The major disadvantage of mini incision technique is limited visualization, but a welldesigned incision and proficiently executed surgical procedure may help to overcome surgical complications. We therefore suggest a limited incision technique to release the carpal tunnel using the nasal speculum and nasal septum knife. This procedure has an advantage over endoscopic procedures in that it may be done as an office procedure and no endoscopic equipment or special training is required.

We evaluated patient outcomes after our mini limited incision technique. The scores of grip strength - key pinch and sensorial evaluations were defined in all patients before and after the surgery by using PSSD. Neurosensory testing with PSSD offers advantages over traditional electrodiagnostic studies. PSSD will identify the earliest stages of nerve compression and neuropathy at a time when traditional electrodiagnostic testing will not be able to detect a change in peripheral nerve function, and therefore PSSD will correlate better with patient symptoms (12-14). The obtained motor and sensory measurements by using PSSD were evaluated by the 'Numerical Grading System' because the nerve conduction studies may be either false positive or negative for diagnosing and evaluating the surgical results. PSSD is also a painless and a noninvasive test and tolerable for the majority of the patients. It therefore may be used to serially follow-up the progression or improvement of carpal tunnel surgery outcomes. Other scoring systems like the

Table I: Pre- and Postoperative Scores for Grip Strength and Pinch Strength.

\begin{tabular}{|c|c|c|c|}
\hline \multicolumn{2}{|c|}{$\begin{array}{c}\text { GRIP (g/ mm2) } \\
\text { (mean } \pm \text { standard deviation) }\end{array}$} & \multicolumn{2}{c|}{$\begin{array}{c}\text { PINCH }(\mathrm{g} / \mathrm{mm} \text { ) } \\
\text { (mean } \pm \text { standard deviation) }\end{array}$} \\
\hline Preoperative & Postoperative & Preoperative & Postoperative \\
\hline $18.4 \pm 3.69$ & $24.4 \pm 4.42$ & $4.4 \pm 2.76$ & $7.4 \pm 2.00$ \\
\hline $15.2 \pm 3.25$ & $23.0 \pm 2.80$ & $3.8 \pm 2.20$ & $5.6 \pm 1.90$ \\
\hline
\end{tabular}


Boston Questionnaire and the Patient Evaluation Measure (PEM) may also be used to evaluate the results obtained from surgical procedures but these systems do not seem to be valuable tools in the evaluation of the symptomatic and functional conditions of patients in carpal tunnel syndrome treatment. The sensitivity and specificity of the questionnaire systems are insufficient as these systems are subjective (12).

There were no complications related to the surgical intervention in our series. The ligament of the carpal tunnel can be divided more effectively under direct vision. The risk for the potential complications and injury to nerve, artery, or tendon decreases remarkably. The only sign of the surgery is a small scar similar to that of endoscopic carpal tunnel release and there are less scar tenderness and pillar pain. There has therefore been almost no need for supplementary treatment such as physiotherapy and anti-inflammatory medication and the patients return to activities of daily living and work within a short time. Our mini incision technique is safe and effective as it offers direct visualization of the structures within the carpal tunnel.

\section{REFERENCES}

1. Con co-nnon MS, Gainor B, Petroski GF, Puckett CL: The predictive value of electrodiagnostic studies in carpal tunnel syndrome. Plast Reconstr Surg 100: 1452, 1997

2. Dellon AL, Keller KM: Computer-assisted quantitative sensory testing in carpal and cubital tunnel syndromes. Ann Plast Surg 38: 493-502, 1997

3. Dellon AL, Nerve Entrapment syndromes. In Mathes SJ, Hentz VR (eds). Plastic Surgery $2^{\text {th }}$ ed. 2006
4. Einhorn N, Leddy JP: Pitfalls of endoscopic carpal tunnel release. Orthop Clin North Am 27: 373, 1996

5. Hans L, Ted A J: Carpal tunnel release through a limited skin incision under direct visualization using a new instrument, the carposcope. Plast Reconstr Surg 98: 313, 1996

6. Kuschner SH, Brien W W, Johnson D, Gellmann H: Complications associated with carpal tunnel release. Orthop Rev 20: 346, 1991

7. Okada M, Tsubata O, Yasumoto S, Toda N, Matsumoto T: Clinical study of surgical treatment of carpal tunnel syndrome: Open versus endoscopic technique. Journal of Orthopaedic Surgery 8(2) : 19-25, 2000

8. Semple J C, Cargill A O: Carpal tunnel syndrome: Results of surgical decompression. Lancet 1: 918, 1969

9. Badger SA, O'Donnell ME, Sherigar JM, Connolly P, Spence RAJ: Open Carpal Tunnel Release - still a safe and effective Operation. Ulster Med J 77 (1): 22-24, 2008

10. S. Avcı U S: Carpal tunnel release using a short palmar incision and a new knife. Journal of Hand Surgery 25B:4: 357 - 360, 2000

11. Tassler PL, Dellon AL: Correlation of measurements of pressure perception using the Pressure-Specified Sensory Device with electrodiagnostic testing. J Occup Med 37: 862-866, 1995

12. Uygur F, Sever C, Yüksel F: Comparing the results of limited incision technique and standard longitudinal incision technique for carpal tunnel decompression by numerical grading system. Turk Neurosurg 19(1):51-57, 2009

13. Weber R, Weber RA, Schuchmann JA, et al: A prospective blinded evaluation of nerve conduction velocity versus pressure-specified sensory testing in carpal tunnel syndrome. Ann Plast Surg 45: 252-257, 2000

14. Yeo K Q, Yeo E M N: Comparison of the results of open carpal tunnel release and KnifeLight. Singapore Med J 48 (12) : 1131, 2007 